\title{
Explaining the 'new' wave of outward FDI from developing countries: the case of Taiwan and Korea
}

Citation for published version (APA):

Dunning, J. H., Narula, R., \& van Hoesel, R. (1996). Explaining the 'new' wave of outward FDI from developing countries: the case of Taiwan and Korea. MERIT, Maastricht Economic Research Institute on Innovation and Technology. MERIT Research Memoranda No. 009 https://doi.org/10.26481/umamer.1996009

Document status and date:

Published: 01/01/1996

DOI:

10.26481/umamer.1996009

Document Version:

Publisher's PDF, also known as Version of record

\section{Please check the document version of this publication:}

- A submitted manuscript is the version of the article upon submission and before peer-review. There can be important differences between the submitted version and the official published version of record.

People interested in the research are advised to contact the author for the final version of the publication, or visit the DOI to the publisher's website.

- The final author version and the galley proof are versions of the publication after peer review.

- The final published version features the final layout of the paper including the volume, issue and page numbers.

Link to publication

\footnotetext{
General rights rights.

- You may freely distribute the URL identifying the publication in the public portal. please follow below link for the End User Agreement:

www.umlib.nl/taverne-license

Take down policy

If you believe that this document breaches copyright please contact us at:

repository@maastrichtuniversity.nl

providing details and we will investigate your claim.
}

Copyright and moral rights for the publications made accessible in the public portal are retained by the authors and/or other copyright owners and it is a condition of accessing publications that users recognise and abide by the legal requirements associated with these

- Users may download and print one copy of any publication from the public portal for the purpose of private study or research.

- You may not further distribute the material or use it for any profit-making activity or commercial gain

If the publication is distributed under the terms of Article $25 \mathrm{fa}$ of the Dutch Copyright Act, indicated by the "Taverne" license above, 


\title{
EXPLAINING THE 'NEW' WAVE OF OUTWARD FDI FROM DEVELOPING COUNTRIES: THE CASE OF TAIWAN AND KOREA \\ forthcoming in International Business Review, 1997
}

by

\author{
John H. Dunning \\ (Rutgers/Reading University) \\ Roger van Hoesel \\ (Ersamus University) \\ and \\ Rajneesh Narula \\ (Maastricht University)
}

\section{Correspondence:}

Dr. Rajneesh Narula MERIT

Maastricht University

PO Box 616

6200MD Maastricht

The Netherlands

fax: 31-43-3216518

e-mail: R.NARULA@MW.UNIMAAS.NL 


\section{EXPLAINING THE 'NEW' WAVE OF OUTWARD FDI FROM DEVELOPING COUNTRIES: THE CASE OF KOREA AND TAIWAN ${ }^{1}$}

Abstract: This paper examines how the characteristics of outward FDI from some of the Asian NIEs differ from the existing literature on third world MNEs (TWMNEs). Using the framework of the revised investment development path, we contend that (i) the second wave of TWMNE activity represents an intermediate stage between the first wave TWMNEs and 'conventional' industrialised country MNE activity; (ii) Such outward FDI activity have been aided by government policies that encouraged the upgrading of $\mathrm{L}$ advantages of the home country which in turn helped create $\mathrm{O}$ advantages of their firms; and (iii) while these $\mathrm{O}$ advantages were initially primarily country-of-origin specific, they have been supplemented through the using of strategic asset-acquiring FDI.

\section{INTRODUCTION}

Beginning with Lecraw (1977), the phenomena of outward FDI by Third World MNEs (TWMNEs) was the subject of considerable amount of research in the late 1970s and early $1980 \mathrm{~s}^{2}$. Much of this research sketched a description of a 'new' kind of MNE that - so it was argued - differed considerably from that of 'conventional' industrialised country MNEs, in terms of its ownership (O) advantages, motivation, geographical direction and mode of overseas activity. In the context of the current study we identify such MNEs as the "first wave investors". Concurrently with this initial empirical evaluation of MNEs from developing countries, several attempts were made to accommodate their activities within existing MNE theory. Two strands are woven through the literature, from two distinct but interrelated points of view. The first, proposed by Lall (1983) and Wells (1983) offered an theoretical justification for the specific characteristics of TWMNEs. The second, and more general, explanation put forward by Dunning $(1981,1988)$ was the investment development path (IDP) which offered, inter alia, an explanation of which countries would engage in outward FDI, and how the level and nature of this activity might be related to, and change with, the economic development of its home country.

Over a decade has passed since these studies were conducted, and, while some recent research has confirmed some of the earlier findings (e.g., Tolentino 1993) there is increasing evidence that there has been a fundamental shift in both the character and motivation of much outward FDI from certain developing countries which we shall argue constitutes the "second wave". The first objective of this paper is to evaluate the outward FDI activity of developing countries in order to determine whether any distinct differences have emerged within the primary outward investors. To what extent have the forces behind globalisation have led to a change in the propensity of developing countries to spawn MNEs that engage in outward FDI? We contend that the 'new' wave of outward FDI are as a result of changes in the structure of the world economy that are a result of globalisation and regionalisation of 
economic activity. These phenomena are associated with, inter alia, (a) dramatic technological advances within sectors, and (b) the liberalisation of markets as well as the establishment of regional trading blocks. It is suggested here that these changes have impacted different countries to different extents, and that the existence of a second wave of TWMNEs may simply represent a subset of the first wave whose home economies have responded more successfully to globalisation.

These changes in the world economy have attracted considerable attention on the theoretical side, too. Absorbing these changes into its framework, the revised version of the IDP (Dunning and Narula 1994, 1996, Narula 1996) ${ }^{3}$ have demonstrated that countries are fundamentally heterogeneous, and the IDP of each country is path dependent and idiosyncratic. Furthermore, the revised version of the IDP introduces certain concepts to the analytical framework, such as the dynamic interaction between growth, FDI and governments, and the growing role of strategic asset seeking investment. The second objective of this paper is to evaluate the revised IDP in light of the evidence reviewed here. In other words, to what extent can existing theory explain the existence of the second wave of outward FDI from developing countries? It is demonstrated in this paper that the second wave is complementary to the first wave, and is simply and intermediate stage of evolution of outward FDI activities as the home country moves along its IDP. Such outward FDI activity has been a result of government-assisted upgrading of $\mathrm{L}$ advantages of the home country which in turn helped create $\mathrm{O}$ advantages of their firms and while these $\mathrm{O}$ advantages were initially primarily country-of-origin specific, they have been supplemented through the using of strategic asset-acquiring FDI.

\section{CHANGING CHARACTERISTICS OF FDI}

In this section we shall examine whether, and to what extent, the activities of TWMNEs have changed in both relative and absolute terms since the 1980s. One of the primary difficulties experienced in examining the evolution of outward FDI from developing countries as a group arises from the quality and standards of data availability. While outward FDI data for developed countries is by and large the same regardless of source, that relating to developing countries is less reliable. For instance, Dunning (1993) and Narula (1996) utilise estimates based on the US Department of Commerce which suggests that total outward FDI stock from developing countries in 1980 was $\$ 15.3$ billion, while UNCTAD (1994) and Tolentino (1993) place the figure at a fifth of that level, or $\$ 3.4$ billion. Even more curiously perhaps, the discrepancies exist in publications by the same source; for example, the estimate for 1980 published in UNCTAD (1995) gives the same stock figure at $\$ 6.1$ billion, twice that of UNCTAD (1994), one year previously. While this inconsistency makes the relative significance of developing country outward FDI vis-a-vis total outward FDI stock vary considerably depending on the data source, the patterns of change over time at the more aggregate level is similar. 
TABLE 1: Significance of Regions in World GDP and outward FDI Stocks, 1980 and 1993

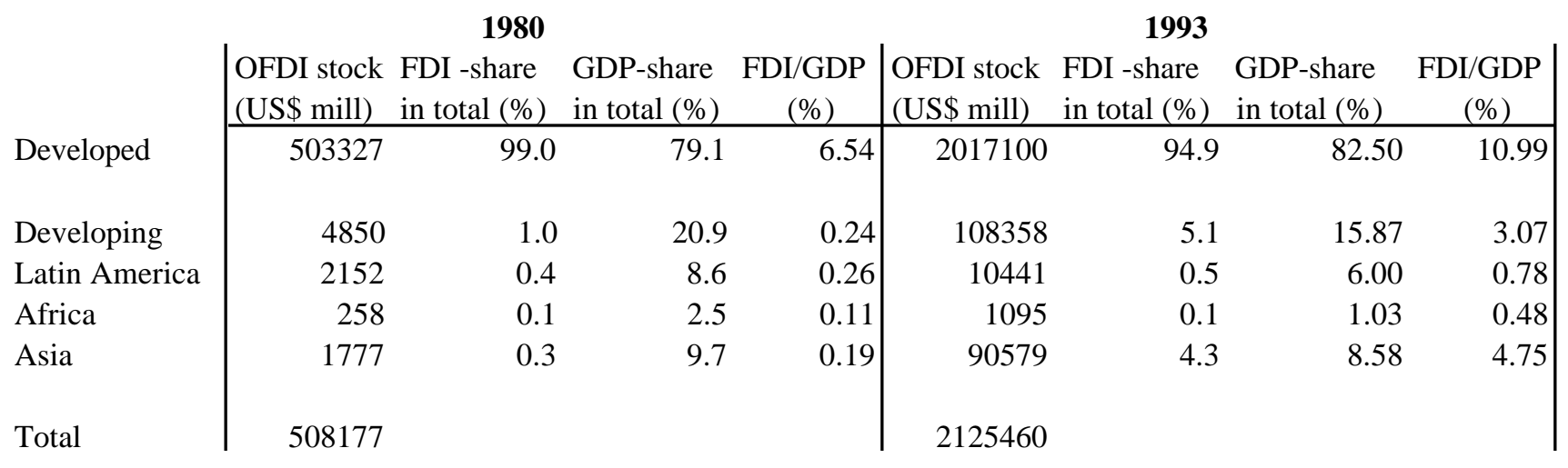

Addenda:

\begin{tabular}{lrrrr} 
developing countries & \multicolumn{2}{c}{$\begin{array}{l}\text { As } \% \text { of total } \\
\text { developing }\end{array}$} & \multicolumn{2}{c}{$\begin{array}{c}\text { As \% of total } \\
\text { developing }\end{array}$} \\
excl. middle east & 4220 & 87.0 & 107530 & 99.2 \\
ASIAN NIEs & 1039 & $21 \%$ & 71860 & $66 \%$
\end{tabular}

SOURCE: UNCTAD 1995, World Bank (1995), Dunning and Narula (eds) 1995

Note: developed countries include all OECD except Mexico.

TABLE 2: Evidence of Catch-up and Convergence among Developing Countries in Outward FDI and GDP Per Capita

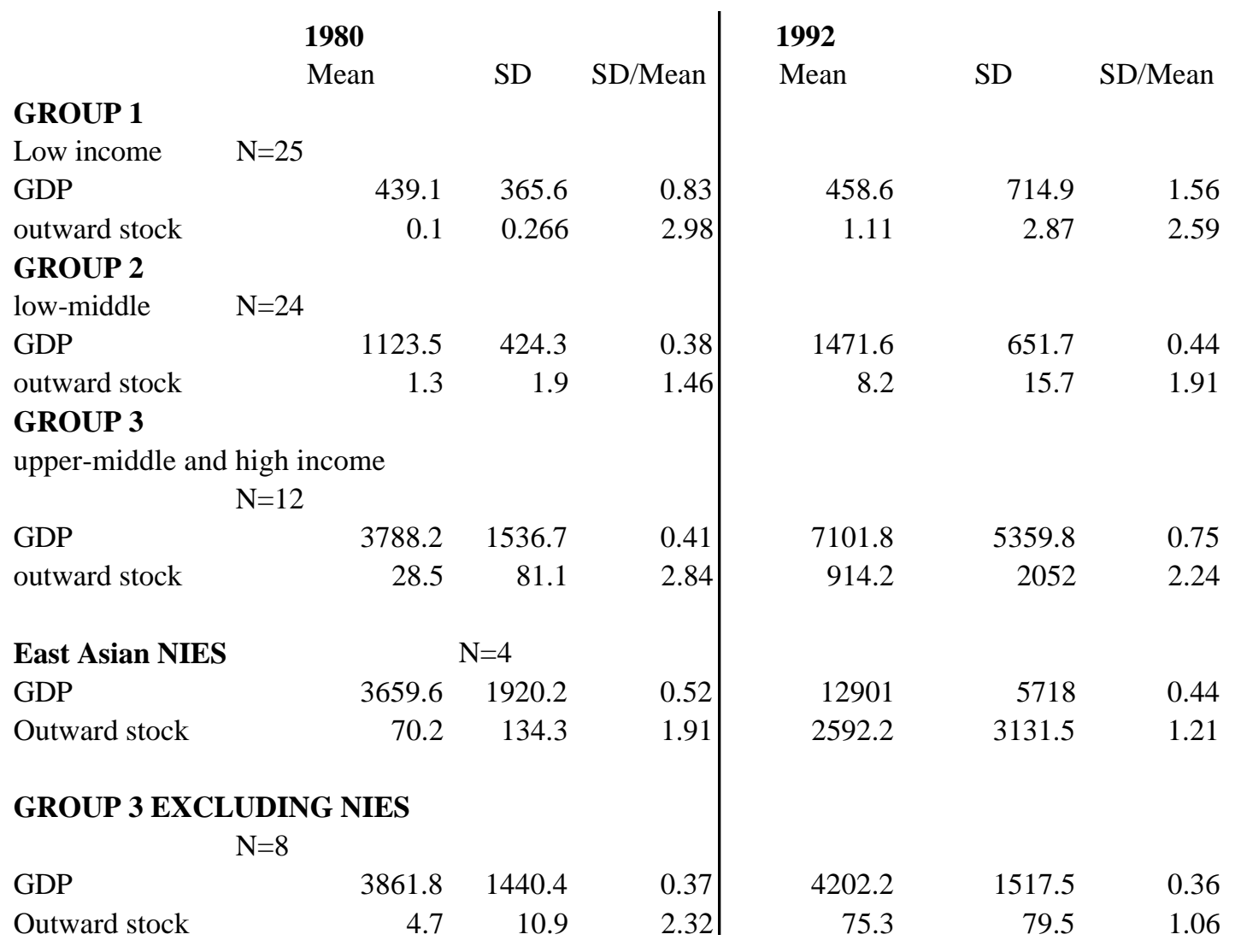

Source: See table 1 
Table 1 gives details of the changing level of outward FDI stock $^{4}$ by major geographical regions and countries for 1980 and 1993, based on UNCTAD data ${ }^{5}$ and classifications. Between 1980 and 1993, outward FDI from developing countries as a group grew from $\$ 4.8$ billion to $\$ 108.4$ billion. In terms of their significance of total outward FDI stock outstanding, these countries increased their share from 1.0\% in 1980 to $5.1 \%$ in 1992 . It is by now an often cited statistic that FDI activity has grown faster than GDP or trade on a world-wide basis (UNCTC 1991). As might be expected of developing economies however, their ownership advantages are insufficient to engage in outward FDI at quite the same pace exports remain much more important to these economies than FDI activities. Table 1 indicates that, outward FDI stock as a percentage of GDP rose from $0.2 \%$ in 1980 to $3.07 \%$ in 1993. In contrast, the share of exports in the GDP of developing countries was almost $17 \%$ in 1993.

\section{****TABLE 2 ABOUT HERE****}

This data would seem to imply that an increasing number of developing countries are engaging in FDI. To what extent is this true for all developing countries? Table 2 gives details of changes in the mean and standard deviation of GDP and outward FDI stock of several sub-groups of developing countries for two periods. The classifications are based on World Bank (1994) estimates, and roughly comply with the first 3 stages of the IDP. For the low income countries (Group 1), Table 2 indicates that there seems to be a greater propensity for least developed countries to engage in outward FDI despite the fact that mean GDP levels of this group have fallen for the group as a whole. However, the high standard deviation would indicate that this seems to be a relatively small phenomena associated with a relatively few countries The same would seem to be true for Group 2 countries. This data would suggest that while more countries are engaging in outward FDI at relatively an earlier stage of development, this appears to be relatively insignificant. Indeed, examining the mean and standard deviation for the two periods in Table 2, it seems that it is only for Group 3 countries and the Asian NIEs that outward FDI seems to have increased to any significant level and has done so uniformly across countries. In other words, outward FDI by developing countries is dominated by a selected number of countries in each group.

While it certainly seems to be the case that outward FDI even by the least developed countries have become the rule rather than the exception, such investments remain rather piecemeal and small in nature. In fact, in several cases this increase in outward FDI may represent flight capital prior to economic liberalisation and the easing of restrictions on capital flows, while in others such as oil exporting economies, large portfolio investments are often recorded as direct investments. Selecting the countries with outward investment greater than $\$ 100$ million in 1980 or $\$ 250$ million but excluding oil-exporting economies, we are able to identify the major outward FDI home developing countries: These are listed in Table 3. Comparing this table to Table 2, it is interesting to observe that of the 25 countries in group 1, China and India account for well over 90\% of all outward FDI from this group in 
1993. There is considerably less concentration in Group 2, where the leading two countries account for just over $50 \%$ of this group(Table 2). In group 3 (excluding NIEs) there is relatively little variation between countries, which are almost all relatively large outward investors, as might be expected of countries in Stage 3 of the IDP.

TABLE 3: Outward FDI for 15 Most Significant Home

Countries, 1980 and 1993

\begin{tabular}{lrrrr} 
& (US\$, Mill) & \multicolumn{3}{c}{ share of total DC OFDI } \\
& $\mathbf{1 9 8 0}$ & $\mathbf{1 9 9 3}$ & $\mathbf{1 9 8 0}$ & $\mathbf{1 9 9 3}$ \\
GROUP 1 & & & & \\
China & 40 & 11802 & $0.82 \%$ & $10.89 \%$ \\
India & 130 & 601 & $2.68 \%$ & $0.55 \%$ \\
GROUP 2 & & & & \\
Brazil & 652 & 4651 & $13.44 \%$ & $4.29 \%$ \\
Colombia & 137 & 476 & $2.82 \%$ & $0.44 \%$ \\
Philippines & 171 & 128 & $3.53 \%$ & $0.12 \%$ \\
Thailand & 13 & 933 & $0.27 \%$ & $0.86 \%$ \\
GROUP 3 & & & & \\
Mexico & 136 & 1039 & $2.80 \%$ & $0.96 \%$ \\
Argentina & 990 & 960 & $20.41 \%$ & $0.89 \%$ \\
Chile & 42 & 1144 & $0.87 \%$ & $1.06 \%$ \\
Venezuela & 185 & 1995 & $3.81 \%$ & $1.84 \%$ \\
Hong Kong & 148 & 41215 & $3.05 \%$ & $38.04 \%$ \\
Korea & 142 & 5555 & $2.93 \%$ & $5.13 \%$ \\
Malaysia & 414 & 4516 & $8.54 \%$ & $4.17 \%$ \\
Singapore & 652 & 6236 & $13.44 \%$ & $5.75 \%$ \\
Taiwan & 97 & 18854 & $2.00 \%$ & $17.40 \%$ \\
Total & 3949 & 100105 & $81 \%$ & $92 \%$ \\
& & & & \\
as \% of developing less & middle east & & & \\
(see Table 1) & & & $93.6 \%$ & $93.1 \%$ \\
& & & &
\end{tabular}

Source: See Table 1

Note: Data for each year represent estimates for closest years available. $\quad *$

It is particularly noteworthy, therefore, that the concentration of TWMNE activity has remained within the same few home countries over time. If one excludes oil-exporting middle east economies, these 15 countries accounted for $93.6 \%$ of all such FDI in 1980, and $93.1 \%$ in 1993 (Table 3). Nonetheless, as Table 3 illustrates, there have been significant changes as to which countries are the primary outward investors. In 1980, the top four home countries in terms of outstanding stock were Argentina, Brazil, Singapore and Malaysia which accounted for $37.4 \%$ of all TWMNE activity, whereas by 1993 , the top four were Hong Kong, Taiwan, China and Singapore, which accounted for $66 \%$ of stock in that year. Table 3 is illustrative of at least three facts: First, that a relatively small group of developing countries are responsible for most TWMNE activity; second, that while this core group has not changed, third world outward FDI is much more concentrated in 1993 than it was in 1980; and third, within this group there has been a considerable change in the countries 
which are responsible for the lion's share of outward activity. It is interesting to note that the dominant countries of the early 1980s, or the 'first wave' investors (primarily South American) generally seemed to have stagnated relative to the dominant investors in the early 1990s, which tend to come from Asian NIEs and 'new' NIEs.

TABLE 4 : characteristics of outward FDI at different stages of the IDP

\begin{tabular}{|c|c|c|c|}
\hline & [STAGE 2] & 'Second Wave' & $\begin{array}{l}\text { 'Conventional' } \\
\text { MNEs } \\
\text { [STAGE 4 AND 5) } \\
\end{array}$ \\
\hline Destination & $\begin{array}{l}\text { regional FDI: neighbouring } \\
\text { countries and other } \\
\text { developing countries }\end{array}$ & $\begin{array}{l}\text { Majority still regional, but } \\
\text { expanding to a global basis }\end{array}$ & Global basis \\
\hline Motivation & $\begin{array}{l}\text { resource seeking \& market } \\
\text { seeking in developing } \\
\text { countries }\end{array}$ & $\begin{array}{l}\text { In developing countries resource } \\
\text { and market seeking in } \\
\text { In industrial countries } \\
\text { asset-seeking and market seeking } \\
\text { in . }\end{array}$ & $\begin{array}{l}\text { Efficiency-seeking - } \\
\text { MNE motivation aimed at } \\
\text { optimising use of each } \\
\text { country's comparative } \\
\text { and competitive } \\
\text { advantages }\end{array}$ \\
\hline $\begin{array}{l}\text { Type of } \\
\text { outward FDI }\end{array}$ & $\begin{array}{l}\text { In developing cties } \\
\text { natural-asset intensive, small } \\
\text { scale production in light } \\
\text { industries (Heksher-Ohlin, } \\
\text { moving towards } \\
\text { undifferentiated Smithian } \\
\text { industries }\end{array}$ & $\begin{array}{l}\text { In developing cties: natural asset } \\
\text { intensive sectors as in first wave; } \\
\text { In industrialised cties } \\
\text { (a) assembly-type, market- } \\
\text { seeking FDI primarily in } \\
\text { Smithian industries } \\
\text { (b) asset-seeking investment in } \\
\text { schumpeterian industries }\end{array}$ & $\begin{array}{l}\text { Capital- and knowledge- } \\
\text { intensive (schumpeterian) } \\
\text { sectors capital/labour } \\
\text { ratio dependent on } \\
\text { natural/created asset of } \\
\text { host. }\end{array}$ \\
\hline $\begin{array}{l}\text { Ownership } \\
\text { advantages }\end{array}$ & $\begin{array}{l}\text { Primarily country-of- } \\
\text { origin-specific. Fundamental } \\
\text { Oa advantages, no Ot } \\
\text { advantages }\end{array}$ & $\begin{array}{l}\text { Both firm- and country- } \\
\text { specific }\end{array}$ & $\begin{array}{l}\text { Mainly firm-specific } \\
\text { Advanced Oa and Ot } \\
\text { advantages. }\end{array}$ \\
\hline $\begin{array}{l}\text { Examples of } \\
\text { ownership } \\
\text { advantages } \\
\text { [adapted and } \\
\text { modified } \\
\text { version of } \\
\text { Lall (1983) } \\
\text { page } 7 \text { ] }\end{array}$ & $\begin{array}{l}\text { 1. Conglomerate group } \\
\text { ownership } \\
\text { 2. Technology (mostly } \\
\text { adapted) } \\
\text { 3. Management adapted to } \\
\text { third world conditions } \\
\text { 4. Low cost inputs (including } \\
\text { managerial and technical } \\
\text { personnel) } \\
\text { 5. 'Ethnic' advantages }\end{array}$ & $\begin{array}{l}\text { 1. Conglomerate group } \\
\text { ownership } \\
\text { 2. Management adapted to third } \\
\text { world conditions } \\
\text { 3. Low cost inputs (including } \\
\text { managerial and technical } \\
\text { personnel) } \\
\text { 4. 'Ethnic' advantages } \\
\text { 5. Some product differentiation } \\
\text { 6. Limited marketing skills } \\
\text { 7. Vertical control over } \\
\text { factor/product markets } \\
\text { 8. Subsidised capital }\end{array}$ & $\begin{array}{l}\text { 1. Large size - economies } \\
\text { of scale } \\
\text { 2. Access to capital } \\
\text { markets } \\
\text { 3. Technology } \\
\text { 4. product differentiation } \\
\text { 5. Marketing know-how } \\
\text { 6. Cross-country } \\
\text { management skills } \\
\text { 7. Globally efficient intra- } \\
\text { firm activity } \\
8 \text { Vertical control over } \\
\text { factor/product markets }\end{array}$ \\
\hline
\end{tabular}

One of the most salient features of TWMNE activity as charted in the first wave literature was the direction and motivation of FDI, compared with 'conventional' MNEs. Table 4 summarises the most salient characteristics of outward FDI by both groups of MNEs. Much of the empirical work indicated a strong and marked trend for TWMNEs to focus their investments in neighbouring and other countries which were at a similar or an earlier stage of their development. This preference was a direct result of their lack of 
international experience - these locations had location advantages that were most similar to those of their home countries. Furthermore, their $\mathrm{O}$ advantages were of a type most suited to these L advantages (and often induced by these L advantages), and were based on technologies which were at the end of their product life cycles. In other words, these MNEs had no transaction-type ownership (Ot) advantages and the most basic form of asset-type $\mathrm{O}$ advantages (Oa) - those that derive from the efficient acquisition and adaptation of imported technologies ${ }^{6}$ (see Table 4). These $\mathrm{O}$ advantages were further enhanced by the prevalence of import-substituting, inward looking policy regimes amongst most developing countries which encouraged small scale production, typical of these TWMNEs. The O advantages of these firms were primarily country-specific, determined by the market distortions introduced by the home country policies, and only sustainable where similar L advantages existed. As Table 5 shows, with almost no exception, at the beginning of the last decade a majority of the outward FDI was directed towards other developing countries, most often neighbouring countries. While some asset-seeking investment in industrialised countries was undertaken? it was relatively minor with many large investments representing flight capital, as entrepreneurs utilised overseas subsidiaries to circumvent home country restrictions on international capital movements and large portfolio investments. In particular cases, a large proportion of what is statistically recorded as outward FDI flows represents investments by the affiliates of 'conventional' MNEs. The case of Hong Kong outward FDI to China is an example of this. The PRC accounted for almost half of Hong Kong total outward FDI stock in 1993, and 66\% of total inward stock in China. Although more recent data is not available, Chen (1983) estimated that just over 50\% of outward FDI from Hong Kong was by affiliates of conventional MNEs in $1981^{8}$. A similar situation also exists in the case of Malaysia and Singapore.

From Table 5 we observe that for most countries in the list, developed countries have become a much more important target. This increase in activity in developed countries can only have occurred if either the $\mathrm{O}$ advantages of investing firms has increased to the extent that they were now able to compete with conventional MNEs on their home turf, and/or these TWMNEs were engaging in a higher extent of asset-seeking FDI. However, this change has not occurred evenly across all developing countries. Cross-referencing Table 3 and 5, the only countries for which the level of their outward FDI in developed countries was significant and increasing in importance (viz., over 20\% of their total outward FDI or greater than $\$ 100$ million in 1993) were Hong Kong, Korea, Taiwan, China and Singapore'. These form the core of the group that comprise the 'second wave' investors. Prominent first-wave countries such as India, Philippines, Argentina and Colombia did not show any significant increase in either the level of the total outward FDI, nor a significant shift towards developed country hosts.

That these first wave countries also experienced very low or negative economic growth rates, and the second wave countries experienced rapid growth over the intervening 
decade and a half is no coincidence. Indeed, in the next section we intend to examine in greater detail how economic changes due both to globalisation and the restructuring due to liberalisation have directly affected the extent and nature of outward FDI activity. In other words, we will examine the underlying developments that have resulted in changes in the $\mathrm{L}$ advantages and the $\mathrm{O}$ advantages of the firms from these countries and the mechanisms that caused these changes.

\begin{tabular}{|c|c|c|c|}
\hline & \multicolumn{3}{|c|}{$\begin{array}{l}\text { Table 5: Geographical Distribution, } \\
\text { Outward FDI Stock, two periods }\end{array}$} \\
\hline & \multicolumn{2}{|c|}{ Developing } & $\begin{array}{c}\text { Developed } \\
\%\end{array}$ \\
\hline \multirow[t]{2}{*}{ India } & 1980 & 91.05 & 8.95 \\
\hline & 1993 & 77.53 & 22.47 \\
\hline \multirow[t]{2}{*}{ China } & 1981 & 35.00 & 65.00 \\
\hline & 1992 & 31.57 & 68.43 \\
\hline \multirow[t]{2}{*}{ Hong Kong } & 1980 & 91.65 & 8.35 \\
\hline & 1990 & 82.08 & 17.80 \\
\hline \multirow[t]{2}{*}{ Argentina } & 1980 & 13.23 & 86.77 \\
\hline & 1990 & 21.46 & 78.44 \\
\hline \multirow[t]{2}{*}{ Brazil } & 1980 & 25.92 & 74.08 \\
\hline & 1990 & 45.93 & 54.07 \\
\hline \multirow[t]{2}{*}{ Chile } & 1990 & 89.00 & 11.00 \\
\hline & 1992 & 93.80 & 6.20 \\
\hline \multirow[t]{2}{*}{ Colombia } & 1980 & 78.00 & 22.00 \\
\hline & 1990 & 75.40 & 24.60 \\
\hline \multirow[t]{2}{*}{ mexico } & 1980 & 23.00 & 77.00 \\
\hline & 1990 & 7.00 & 93.00 \\
\hline \multirow[t]{2}{*}{ korea } & 1978 & 75.90 & 24.10 \\
\hline & 1994 & 49.00 & 51.00 \\
\hline \multirow[t]{2}{*}{ Taiwan } & 1978 & 79.00 & 21.00 \\
\hline & 1994 & 77.20 & 22.80 \\
\hline
\end{tabular}

Source: See Table 1

\section{BACKGROUND OF THE SECOND WAVE}

In order to explain the second wave, let us first return to the IDP. According to the IDP, countries at Stage 2 are home to firms engaging in elementary outward FDI. As they acquire experience in their international operations (thereby improving their $\mathrm{O}$ advantages), and as the $\mathrm{L}$ advantages of the country improve over time, they engage in an increasing extent of outward FDI. The interaction between FDI activities and development that underpins the concept of the IDP is essentially idiosyncratic and unique to each individual country. Nonetheless, there is a general pattern that, as these countries develop, they enter and progress through Stage 3 of the IDP, viz, these MNEs gain further experience in international business activities and develop $\mathrm{O}$ advantages that can be increasingly exploited 
in overseas markets. Indeed, as we have seen from the evidence given in the previous section and elsewhere (see e.g., Hikino and Amsden 1994), many of the first wave home countries have remained in Stage 2, having experienced no economic growth and improvement in their $\mathrm{L}$ advantages. It comes as no surprise, therefore, that their competitive advantages of their MNEs have not evolved either. Conversely, the second wave countries have experienced rapid economic growth.

This has been further enhanced by the fundamental (but gradual) change in the structure of the world economy, much of which is often generalised as being a direct result of globalisation. These changes can be considered from the developing country perspective as being of two kinds. First, there are those that have been largely exogenous to these countries individually but which have affected their economic structure both as members of the world economic order and as individual economies. Whereas industrialised countries have been experiencing economic, technological and structural convergence, the majority of developing countries, rather than converge, with the lead countries both economically and technologically ${ }^{10}$. These simultaneous processes of convergence and divergence has impacted on firms by creating broader and more competitive markets across countries due to similar consumption and production patterns. This has had two effects on the converging countries: (i) Firms in each country are presented with larger markets, and this has led to developing global technologies that have large economies of scale and high minimum efficient scale. The upshot of this is that firms in these industrial sectors need international markets to justify production; and (ii) Technologies have also converged, such that firms in certain sectors are now competing not just with other firms in the same country, but other firms in the same country but not necessarily in the same industry (Cantwell and Sanna Randaccio 1990). In other words, firms need to have competitive advantages that are globally viable, rather than domestically or regionally so, and this has been further enhanced by space-shrinking technologies (Dicken 1993). Although the development of de facto and de jure economic blocs such as EU and NAFTA within the Triad has primarily acted to enhance the positive effects of these developments for their members, they also represent barriers to entry to nonmembers and to developing countries in particular.

Second, there have been structural changes within individual countries often in direct response to these changes, and as such may be considered as endogenous to developing countries. These endogenous changes are primarily associated with the actions and policies of governments. One of the most important change over the past decade or so has been a fundamental shift in the policy orientation of developing countries from a import-substituting role to a export-oriented, outward looking one. The extent of liberalisation varies from country to country: in some cases it is associated with a more pro-active and market facilitating role, while in other countries it is simply reactive or even laissez-faire. Nonetheless, despite this broad spectrum of policy options, it is safe to generalise that the extent of government intervention in the developing world covers a much wider variation 
than was the case 15 years ago, and this variation is equally diverse with regards policy orientation towards MNE activity ${ }^{11}$ (see UN 1995). This fundamental policy shift has led to a decline in the $\mathrm{L}$ advantages of developing countries and a subsequent decline in the countryof-origin-specific $\mathrm{O}$ advantages of their firms. We address these issues in greater detail below, before turning to an illustration of two prominent second wave countries in Section 3 .

2.1 Stagnation of the outward FDI from first wave countries. As discussed in Section 1 and Table 4, the $\mathrm{O}$ advantages of first wave investors were primarily country- (rather than firm-) specific in nature and based on barriers to entry due to import-substituting regimes. Outward FDI from these countries benefited from similar market conditions in host countries and thus enjoyed similar L-specific $\mathrm{O}$ advantages overseas. With this broad liberalisation, such $\mathrm{O}$ advantages declined both at home and abroad, inter alia due to the increase in competition with conventional developed country MNEs which are able to exploit their superior Oa and Ot advantages on a global scale, and which already have economies of scale and scope. Indeed, this change in economic stance often occurred due to the economic decline of these countries which led to economic restructuring, of which the withdrawal and/or stagnation of their MNEs from outward FDI activity was symptomatic. Such promising first wave investors as India, Philippines, Argentina, Mexico and Colombia were countries which experienced very low or negative GDP growth rates over much of the 1980s.

The increase in TWMNE activity directed towards developed countries across both the first wave and the second wave home countries (Table 5) despite a decline in competitive advantages of first wave MNEs does seem, at first sight, to be somewhat contradictory. However, the increase in north-south competition due to liberalisation has created an imperative to undertake asset-seeking FDI: Firms from these countries must upgrade their Oa advantages if they are to survive even in their home countries. Globalisation, therefore, has shortened the product life cycle concept, and forced these countries to actively restructure their economies. An $\mathrm{O}$ advantage based on obsolete technologies is no longer an asset capable of providing economic rent, since firms in a liberalised world must successfully compete with all other firms regardless of location. This, perhaps more than any other fact, helps explain the relatively lower threshold at which developing countries engage in outward FDI, although it remains quite insignificant in absolute terms for Stage 1 countries.

\subsection{Economic transformation of the Second Wave countries}

Although the fact that a small subset of the first wave of TWMNEs form the second wave, it is as much the success of the second wave as it is the 'stumbling back' of the first wave that underlies their success. The success and evolution of MNEs from the second wave countries is not surprising due to their rapid economic restructuring and economic development, as suggested by the IDP. 
This industrial restructuring has also led to an increasingly geographical spread of outward FDI activity beyond simple regional, comparative advantage-based relocation of production, and is indeed a central feature of the second wave (Table 4). This shift towards a more global attitude can be seen as occurring due to two main changes. First, high R\&D costs in innovation-intensive sectors have forced MNEs of all nationalities to seek larger markets in order to justify production. As the second wave countries have moved along the IDP and towards more assembly oriented or innovation-intensive sectors they too have needed to be globally competitive in order to achieve economies of scale. With economic liberalisation this need has been further enhanced - it is no longer sufficient to be regionally competitive, but globally competitive. While it may still be more cost-effective to engage in exporting, there remain strategic benefits of locating some production activity in the major developed country markets, both to avoid protectionist policies as much as to more efficiently develop marketing and service operations.

The second reason is associated with the need to continue upgrading $\mathrm{O}$ advantages. The competitive advantages of TWMNEs lie primarily in their ability to co-ordinate activities across sectors which are transaction-type $\mathrm{O}$ advantages. However, their asset-type $\mathrm{O}$ advantages tend to be in the latter stages of their product life cycles. The technologies underlying these asset-type $\mathrm{O}$ advantages were in natural asset intensive and undifferentiated technologies (characteristic of Stage 2 countries), which were relatively easily available through arms-length or joint venture agreements. However, markets for innovation intensive and cutting edge technologies do not have markets that are as well defined, if at all. Furthermore, even where markets do exist, the firms that have proprietary rights to these technologies have become wary of the potential for direct competition with leading second wave firms, and are quite reluctant to provide them (Contractor 1993). As such TWMNEs are left with the choice of engaging in expensive (and highly uncertain) R\&D, or they may seek access through market seeking investments in developed countries. This theme is also explored in greater depth in the next section.

This dichotomy of two types of TWMNE activity is not entirely new. In fact a similar debate was prompted by Japan's outward FDI activity particularly during the 1970s, whose outward FDI characteristics at the time were very similar to today's second wave countries (Table 4). Indeed, during the period in question, Japan was in Stage 3 of the IDP (Dunning and Narula 1994). Indeed, the similarity of Japanese outward FDI in the 1970s to those of Korea and Taiwan currently is not entirely coincidental. It is worth noting that as Japan has progressed to Stage 4 and 5, the differences between Japanese MNEs and the then'conventional' MNEs which were highlighted by Kojima (1978) have essentially disappeared. In other words, the evolution of developing country outward FDI and the 'unique' characteristics of the first and second wave outward FDI simply represent the natural evolution of MNE activity as their home countries and experience with overseas production increases. Indeed, as Table 4 shows, the characteristics of the second wave could 
be regarded as an intermediate stage between 'conventional', industrialised country MNE activity and first wave outward FDI.

Underlying these differences between the first and second wave is the role of governments in determining the rate and direction of the economic growth and restructuring, all of whom are regarded as East Asian NIEs or 'new' NIEs. Much has been written about these 'East Asian miracles' (World Bank 1993, Wade 1990), most of which has emphasised the primary role of governments in fostering economic development and restructuring, and which was absent in those countries which have stagnated since the first wave. The exploits of second wave TWMNEs have been subsidised by governments with government policy interacting (often positively) with the strategy of firms. We illustrate this with evidence from Korea and Taiwan in the next section.

\section{ILLUSTRATING THE SECOND WAVE}

\subsection{Geographical and industrial distribution}

Table 6:Distribution of Outward FDI Stock from Korea and Taiwan, Selected Years

\begin{tabular}{l|rr|rr|rr} 
& $\mathbf{1 9 7 8}$ & & $\mathbf{1 9 8 8}$ & & $\mathbf{1 9 9 4}$ & \\
& KOREA & TAIWAN & KOREA & TAIWAN & KOREA & TAIWAN \\
Southeast Asia & $52.5 \%$ & $70.8 \%$ & $25.7 \%$ & $30.1 \%$ & $41.9 \%$ & $26.8 \%$ \\
$\quad$ PRC & & $0.0 \%$ & & $0.0 \%$ & & $33.8 \%$ \\
Europe & $2.8 \%$ & $0.3 \%$ & $3.8 \%$ & $2.8 \%$ & $12.8 \%$ & $3.7 \%$ \\
N. America & $18.7 \%$ & $16.5 \%$ & $43.4 \%$ & $60.1 \%$ & $35.3 \%$ & $18.7 \%$ \\
Latin America & $1.8 \%$ & $7.4 \%$ & $2.7 \%$ & $4.1 \%$ & $3.1 \%$ & $16.1 \%$ \\
Oceania & $2.6 \%$ & $4.2 \%$ & $7.8 \%$ & $2.0 \%$ & $2.9 \%$ & $0.4 \%$ \\
Other & $21.6 \%$ & $0.8 \%$ & $16.7 \%$ & $0.9 \%$ & $4.0 \%$ & $0.5 \%$ \\
& & & & & & \\
Total amount & & & & & & \\
(US\$ '000) & 71576 & 49896 & 1130108 & 593319 & 7648792 & 13449269
\end{tabular}

In this section, we will illustrate our analysis by the experience of two prominent second wave investors, Korea and Taiwan. Table 6 sets out the geographical direction of Korean and Taiwanese outward FDI stock for a number of years. In the case of Korea, we observe that, at the end of 1978, when only a very modest US\$ 71.6 million had been invested, more than half went to countries in the Asian region; however by the end of 1994 the share of those countries had fallen to about $41.9 \%$. Within Asia, no less than $71.3 \%$ of Korean FDI has gone into manufacturing, followed by mining $(10.7 \%)$ and trade $(7.4 \%) .{ }^{12}$ China received the bulk of Korean FDI invested in Asia, and accounted for $35.5 \%$ of FDI stock in Asia by 1994. This is quite remarkable since investments into China only gained momentum from 1992 onwards. By 1994 North America had become the second most popular region for Korean investors, hosting 35.3\% of outstanding FDI. Table 7 indicates 
that investments made in North America have, unlike FDI in Asia, not been as concentrated in manufacturing: trading activities were more important $(39.3 \%)$, whereas $42.7 \%$ was in manufacturing. Since 1988, the share of North America has gone down, while the presence of Korean firms in Europe has extended considerably having attracted $12.8 \%$ of outstanding FDI by the end of 1994. In Europe, manufacturing (51.4\%) and trade (41.7\%) are by far the most important recipients of Korean FDI. 
TABLE 7: Sectoral and Geographical Distribution of

Outward FDI Stock for Korea and Taiwan, 1994, percentages

\section{KOREA}

S.E. Asia N. America

Europe Other Areas Total

$\begin{array}{lccccc}\text { Mining } & 10.7 & 4.1 & 4.6 & 23.6 & 8.9 \\ \text { Forestry } & 1.0 & 0.0 & 0.0 & 6.0 & 1.0 \\ \text { Fishery } & 0.5 & 0.9 & 0.2 & 8.1 & 1.4 \\ \text { Manufacturing } & 71.3 & 42.7 & 51.4 & 32.6 & 54.8 \\ \text { Construction } & 0.8 & 2.2 & 0.0 & 6.7 & 1.8 \\ \text { Transportation } & 0.6 & 0.5 & 0.1 & 1.0 & 0.5 \\ \text { Trade } & 7.4 & 39.3 & 41.6 & 5.8 & 22.9 \\ \text { Others } & 3.4 & 10.0 & 1.3 & 16.1 & 6.7 \\ \text { Real estate } & 4.2 & 0.4 & 0.6 & 0.1 & 2.0 \\ \text { Total } & 100.0 & 100.0 & 100.0 & 100.0 & 100.0\end{array}$

TAIWAN

S.E. Asia China N. America Europe Other Total

$\begin{array}{lcccccc}\begin{array}{l}\text { Mining } \\ \text { Agric. \& } \\ \text { forestry }\end{array} & 0.1 & 0.2 & 0.0 & 0.0 & 0.1 & 0.1 \\ \begin{array}{l}\text { Fish. \& } \\ \text { anim. husb. }\end{array} & 0.4 & 0.4 & 0.0 & 0.0 & 0.0 & 0.2 \\ \begin{array}{l}\text { Manufacturing } \\ \text { Construction }\end{array} & 0.0 & 0.5 & 0.0 & 0.0 & 0.2 & 0.2 \\ \begin{array}{l}\text { Transportation } \\ \text { Trade }\end{array} & 0.6 & 0.3 & 1.9 & 0.0 & 2.1 & 1.0 \\ \begin{array}{l}\text { Banking } \\ \text { \& insur. }\end{array} & 1.2 & 0.5 & 0.8 & 0.0 & 5.1 & 1.5 \\ \begin{array}{l}\text { Others } \\ \text { Total }\end{array} & 7.9 & 2.0 & 7.6 & 12.0 & 12.4 & 7.3 \\ & 6.1 & 0.1 & 23.3 & 14.7 & 60.6 & 17.1 \\ & 100.0 & 100.0 & 100.0 & 100.0 & 100.0 & 100.0\end{array}$

The situation was similar in the case of Taiwan (Table 6 and 7). At the end of 1978, firms had invested only on a very limited scale abroad (US\$ 49.9 million). ${ }^{13}$ A great majority 
$(70.8 \%)$ at that time was directed to Southeast Asia, whereas $16.5 \%$ was invested in North America. Although officially approved 'indirect' FDI ${ }^{14}$ into the PRC have been registered only since 1991, their influence on the regional distribution of Taiwanese investments abroad is substantial. By 1994, the PRC had become the single most important host country for Taiwanese firms, having received $33.8 \%$ of total approved outward FDI. A great majority $(93.4 \%)$ has been invested in the manufacturing sector. The dominant position of Asia as a host region is further underscored by the position of the 'rest of Asia' which by the end of 1994 had attracted another $26.8 \%$ of Taiwanese FDI. Also here, most FDI has flown into manufacturing (74.5\%). As a result of the spectacular increase of FDI in the Asian region, the share of North America has gone down from $60.1 \%$ to $18.7 \%$ in the last six years. In this region, $56.8 \%$ of Taiwanese capital has been invested in manufacturing and a remarkable $23.3 \%$ in banking and insurance sector. ${ }^{15}$ Although Europe's share has gone up, it is still not a very popular destination for Taiwanese firms.

\subsection{Transforming the economy and outward investment}

The explanations behind the second wave of Korean and Taiwanese FDI are almost all directly or indirectly related to shifts in the structure of the world economy and especially the transformation of their own economies. This transformation has implied a simultaneous upgrading of the domestic industrial structure and phasing out of 'incompatible' industries. In both economies the industrial structure has evolved from being primarily based on labourintensive ('Heckscher-Ohlin') manufacturing (such as textiles, sundries and other light industry goods) as the leading export sector to 'undifferentiated Smithian' industries (based on scale economies such as heavy and chemical industries) and 'differentiated Smithian'

industries (assembly based, subcontracting dependent) such as automobiles and electric/electronic goods. ${ }^{16}$

This process of industrial upgrading reflects important changes in the OLI configurations and subsequent shifts from Stage 1 of the IDP to stages 2 and 3. However although there are some broad similarities, the IDP of both countries have been fundamentally different. Most prominently, firms from either country accumulated new $\mathrm{O}$ advantages through conspicuously different means. In the case of Korea, the government has primarily fostered a licensing strategy, avoiding FDI and wholly owned MNE affiliates as much as possible. With the exception of the electronics industry, inward FDI has not contributed greatly to Korea's technological capabilities. From the mid-1960s onwards, the authorities preferred joint ventures (with minority foreign ownership) to wholly foreign owned subsidiaries. From the mid-1970s licensing agreements became more important than FDI as a technology source (Ernst and O’Connor, 1989). In Taiwan, on the other hand, since the initiation of an export-oriented industrialisation policy in the 1960s, inward FDI was encouraged and the authorities played an active role in maximising the benefits MNEs can offer by matching domestic L and O advantages in an optimal manner (van Hoesel, 1996). For many companies in both Korea and Taiwan, OEM contracts with leading industrial 
companies (e.g., in electronics) have also considerably contributed to their $\mathrm{O}$ advantages primarily as far as the development of production capabilities is concerned (ESCAP, 1991). ${ }^{17}$ In attempting to reduce the dependence on Japanese and US sources, the Korean and Taiwanese governments in recent years commenced to boost indigenous R\&D efforts on a larger scale.

As we indicated already, changing $\mathrm{L}$ advantages has also meant the phasing out of industries for which comparative advantages began to erode - a process also witnessed in industrialised economies in the past. According to Ozawa (1992, 1995), in the 'tandem industrialisation' process, the advanced nation's superiority in industrial structure and technological progress is transmitted to lower-echelon nations. The upgrading from Heckscher-Ohlin type to Smithian industries led, inter alia, to a discrepancy between early L advantages (such as cheap labour) and the $\mathrm{O}$ advantages needed in subsequent stages. This is accompanied by so-called 'Ricardian bottlenecks'. Shortage of low-skilled labour pushed wages up, a trend that was reinforced by democratisation tendencies which gave more room for wage demands by labour unions. ${ }^{18}$ These wage increases were not matched by productivity growth. Especially in Taiwan, domestic L advantages were further worsened as a result of its sizeable exchange reserves (one of the largest in the world) that put inflationary pressure on the domestic economy and led to high price levels in the non-tradable sector such as real estate and stock market (San Gee, 1992). These developments made companies decide to shift their more labour intensive production activities to countries where labour is cheap and abundant. Most of these resource seeking FDI stayed in the region (going to new NIEs (mostly ASEAN) and 'new' new NIEs (such as the China), although investments are also increasingly made in relatively less advanced economies outside the region but in the vicinity of important Triad markets (North America, EU). As in the case of FDI in Asia, these 'satellite economies' in Eastern Europe or Latin America offer cheap resources and, in addition, often established favourable import regulations with target markets.

Upgrading the domestic economy has also led to more intense direct competition with producers from major trading partners. As a response to their export success, the US authorities (for both the most strategically important market) forced local currencies to appreciate. $^{19}$ This clearly made exporting from the home economies less attractive, stimulating FDI in production facilities overseas.

As compared to the first wave, Korean and Taiwanese FDI has become less of a primarily regional phenomena. Smithian industries require $\mathrm{O}$ advantages based on scale/scope making the maintenance and expansion of markets overseas (especially for relatively small economies such as Korea and Taiwan) mandatory. Threats of protectionism have induced Korean firms in some industries (such as consumer electronics) to shift production to within the borders of major economic blocks such as the European Union and NAFTA. These market seeking/retaining investments have not been without problems, however. In their study on FDI by Korean firms in the electronics industry, Jun and Yoon 
(1995) concluded that investments in developed countries have been premature and were a 'life or death decision'. According to them, O advantages common to 'conventional' MNEs are not present; instead these firms are dependent on home country L advantages. Precisely this insufficiency of $\mathrm{O}$ advantages needed to become global competitors in medium to high technology intensive industries form another motivation to invest in economically advanced regions. Frontier technology is not easily available through arm's length transactions. Although strategic alliances have emerged as an increasingly important mode to generate new technologies, as opposed to 'conventional' MNEs only a limited number of Korean companies and only very few Taiwanese firms are technologically advanced enough to have something to offer vis-a-vis potential partners. Therefore, next to technological efforts carried out at home, the second wave contains an increasing number of strategic asset seeking investments by Korean and Taiwanese firms meant to accumulate new $\mathrm{O}$ advantages in Triad economies.

Another major reason for the expansion of value adding activities in the Triad is the accumulation of $\mathrm{O}$ advantages related to marketing capabilities. This is one of the primary motivations for the increased M\&A activities of firms from these countries. Since many Korean and Taiwanese firms initially primarily sold their products through OEM arrangements, building up global brand names and distribution channels has often been neglected in the past. To expand its sales network, President Foods Inc., the biggest Taiwanese food processing company, for instance bought Wyndham Foods, the third largest biscuit manufacturer in the United Sates. The Taiwanese Acer Group acquired US-based Counterpart Computers which gave Acer access to the minicomputer business. In its search for production know how for special steels, the Korean Sammi Group purchased the steel division of Atlas Corporation of Canada. Recently, Samsung took a substantial stake (almost $50 \%$ ) in US computer firm, AST. This move made Samsung/AST the fifth largest PC maker in the world and can be considered an attempt to strengthen Samsung's weak position in information systems resulting from a poor international brand name recognition and inadequate sales channels abroad (Business Korea, 1995).

Next to M\&A activity, greenfield investments in industrialised countries have also offered the opportunity to scan the local business environment. Examples are the many Taiwanese computer firms that have affiliates in Silicon Valley to tap locally available technological know how, or LG Electronics' Design Centre in Ireland (Dublin) where products are designed that are tailored to European lifestyles.

Notwithstanding these efforts to accumulate the $\mathrm{O}$ advantages needed to break into advanced economies through FDI, most Korean and Taiwanese firms have not yet reached the same technological and commercial level as MNEs from industrialised economies. How then can their production presence in Europe and North America be explained? In most cases, the local content of these activities is rather low implying that a substantial share of intermediate products is still produced in Korea, Taiwan or elsewhere in Asia. This suggests 
that for the most part the $\mathrm{O}$ advantages of Korean and Taiwanese firms are still based on country- or region-of-origin specific $\mathrm{O}$ advantages. Moreover, leading Korean and Taiwanese companies typically have built up a strong presence in third world countries and economies in transformation (e.g., Eastern Europe). In these environments, these firms can still compete on the basis of their 'traditional' first wave strengths, such as knowledge of the local environment and small-sized production. Furthermore, Korean consumer electronics companies and Taiwanese computer firms (both important outward investors) in most cases supply the lower end of their markets - thus avoiding direct competition with MNEs from industrialised economies.

At the same time, the rapid advance of Korea and Taiwan to the third Stage of the IDP would not have been possible without a major change in government policy with regard to outward investment (UNCTAD 1995). During the first wave, government policies towards outward FDI in most developing countries mainly consisted of capital export restrictions to keep investments at home (UNCTAD 1995). Also in Korea and Taiwan outward FDI for a long time was severely restricted. This attitude changed in the second half of the 1980s when the Korean and Taiwanese authorities, being confronted with eroding traditional comparative advantages and growing needs of indigenous firms to seek new assets overseas, decided to drastically liberalise their policy with regard to capital outflows. Since 1992, Korean FDI policy even became part of the nation's industrial policy. Extensive support is rendered to potential overseas investors, among others by means of financial support and tax incentives. It is known for instance that takeovers as well greenfield ventures are often partly financed by cheap government credits thus providing an additional competitive edge (Hikino and Amsden 1994). Although less extensive than in the case of Korea, also in Taiwan financial and tax arrangements are available for outward investors. The support measure illustrate the holistic government policies pursued in Korea and Taiwan (where conventional and nonconventional) inward as well as outward investment as a integrated policy integrated in the general economic policy aimed at a continuos upgrading of the domestic economy.

\section{$\underline{3.3 \text { Idiosyncratic FDI patterns }}$}

According to the IDP, individual countries show their own subpatterns of (inward and) outward investment, depending among others on the role of governments and the way in which economic activities are organised (Narula, 1996). It is widely acknowledged that the Korean and Taiwanese economies share important characteristics (such as their outward orientation) - even as far as the moment of emergence of indigenous MNEs is concerned. Nonetheless, important variations in their 'business systems' have clearly influenced the nature of ODI from both countries and can be expected to do so in the future. ${ }^{20}$

The most apparent difference concerns the size of leading firms ${ }^{21}$ or, more in general, the industry structure. In Korea, strong state intervention (based on a strong belief in the importance of scale advantages) allowed only a limited number of companies in strategic 
industries (such as consumer electronics and automobiles). This oligopolistic structure has led to giant enterprises (e.g., Samsung, Hyundai, Daewoo, Ssangyong) that, especially in the past, received heavy government support. In Taiwan, on the other hand, the domestic economy is still dominated by small and medium sized family firms (Kuo, 1993), characterised by less vertical integration and depending heavily on contracting relations.

Partly as a result of these differences in industry structure also distinct strategic orientations of companies can be observed. The Korean 'chaebol' (conglomerates) are prepared to invest heavily in realising high volume production and gaining market share even if unit costs exceed prevailing market prices. Because of the small size and more limited government support, Taiwanese companies usually follow a so-called 'bootstrap' strategy. At the core is the continuous exploration of new niche markets for non-standardised products. This implies a more opportunistic approach emphasising short pay-back periods on investments. This short term orientation has a clear restrictive effect on the possibilities of FDI in advanced economies where substantial financial and organisational commitment are required. As a result, Taiwanese FDI in production facilities in advanced economies in most cases is limited to assembly type operations. Attempts as made by some of the Korean companies to integrate more deeply in overseas economies (and thereby advance further toward becoming a truly 'global' company) are hardly observed in the case of firms from Taiwan. Also, the costly R\&D expenditures needed to improve a company's technology capabilities and massive marketing costs required to build up own brand names are usually related to large sized firms.

Another important determinant of the geographic distribution of outward FDI in the case of Taiwanese companies are the relations with other ethnic Chinese communities, especially in Southeast Asia and particularly the PRC. Extensive networks with Chinese entrepreneurs abroad in many cases support operations in these countries. For the many labour intensive small family firms being confronted with worsened domestic L conditions and at the same time lack crucial $\mathrm{O}$ advantages such as international experience and foreign language capabilities (Kuo, 1993), these contacts are of prime importance. In other words, ethnic links in many cases have not only influenced the direction of Taiwanese investments, but have meant the survival of many smaller sized firms. In the case of Korean firms, ethnic links abroad have been only of minor importance and have certainly not stimulated the decision to go abroad.

\section{CONCLUSIONS}

This paper has confined itself to addressing two questions regarding the outward FDI of developing countries in light of globalisation. The first question pertained to whether TWMNE activity had undergone a fundamental shift that might be considered as constituting a distinct second wave of outward FDI activity that was distinct from that described by the research conducted in the early- and mid-1980s (referred to as the first wave). The evidence 
suggests that this was indeed the case although the two ways are not separate and distinct. The second question was whether this 'new' wave could be usefully explained within the framework of the IDP (Dunning and Narula 1994, 1996, Narula 1996). The evidence presented here suggests that the evolution from the first wave to second wave is entirely consistent with the predictions of the IDP and the analysis of Ozawa $(1992,1995)$, since the waves are complementary to each other- each appropriate to the home country's extent and pattern of economic development.

The evidence presented here indicates that the second wave consists mainly of the East Asian NIEs. The second wave represents part of a continuum, and can be best characterised as an intermediate stage in the evolution of MNE activity, between the first wave TWMNEs and conventional MNEs (see Table 4). Such growth has been conditional on the improvement of $\mathrm{O}$ advantages of firms resulting inter alia from a continuos upgrading of $\mathrm{L}$ advantages of the home country. While improved $\mathrm{L}$ advantages are a natural consequence of economic development and restructuring as they move from Stage 2 to Stage 3, this process has been accelerated by their holistic and integrated government policy towards industrial development. This has not only helped upgrade L advantages but they have also played a pro-active role in promoting outward FDI not just as a means to achieve structural adjustment but to develop new $\mathrm{O}$ advantages of their firms. This active aspect of governments, which they have practised for three decades as part of an outward looking, export-oriented policy, is something that sets the second wave countries apart from the first wave - it is no coincidence that economic liberalisation and abandonment of importsubstituting orientation occurred more recently amongst the first wave countries that did not progress to the second wave.

Indeed, it is this last point that is as much behind the emergence of the second wave as their economic success. The 'stumbling back' (Hikino and Amsden 1994) of a large number of developing countries makes the success of the second wave countries much more apparent. The decline in the $\mathrm{L}$ advantages of these countries due to structural adjustment programmes has also led to the decline of the $\mathrm{O}$ advantages of the first wave TWMNEs. These $\mathrm{O}$ advantages were primarily country-specific, often a result of barriers to entry associated with import-substituting programmes. Such firms tended to invest overseas only in countries which have similar L advantages. With economic liberalisation, their has been a decline in these $\mathrm{L}$ advantages, and consequently, the $\mathrm{O}$ advantages of their MNEs.

The second wave countries are in fact at Stage 3 of the IDP, and as might be expected of countries that are currently industrialising, have evolved economically towards industrial sectors which are capital and knowledge intensive. They are engaged in outward FDI in Stage 1 and 2 countries as a means of moving their natural-asset intensive activities to locations with appropriate comparative advantages, while at the same time securing markets in the Stage 4 and 5 countries and engaging in a certain amount of strategic asset-seeking activity. In other words, they are increasingly becoming global, demonstrating features of 
'conventional' MNEs. This 'hybrid' type of MNE activity is not entirely new - similar observations were made with regards Japanese MNEs two decades previously (see e.g., Ozawa 1979, Kojima 1978) when it was at Stage 3 of the IDP (Dunning and Narula 1994). One of the primary differences between the second wave countries and Japan has been the much more active promotion of outward FDI activity in general and strategic asset-seeking investments. This may have something to do with the process of globalisation where it is no longer simply desirable to be globally competitive, but essential to be so.

Our illustration of the second wave using evidence from Korean and Taiwan confirms that broad classifications disguise, but do not obliterate, country-specific differences due to idiosyncratic differences due to natural and created asset endowments. While these two countries broadly resemble each other in terms of outward FDI activity, government policy in many ways could not have been more different. This is an area which warrants much further in-depth study, especially in understanding such issues as the implementation of government policy to improve $\mathrm{L}$ advantages, the efficacy of manipulating market structure, and the extent to which inward MNE activity can improve the $\mathrm{O}$ advantages of domestic firms.

Hot on the heels of the NIEs, are the new NIEs, and the 'new' new NIEs that have adopted or implemented variations of the policies utilised so successfully by the second wave countries. Already considerable interest has been generated by the activities of MNEs from China, Indonesia and Malaysia, to name but a few. These countries are already beginning to exhibit similar patterns of outward FDI activity (see e.g., Lecraw 1993, van den Bulcke and Zhang 1996) as they move towards Stage 3. 


\section{REFERENCES}

Business Korea, 1995: Challenging the Global PC market, Business Korea,.April. p 25

Cantwell, J. and Sanna Randaccio, F.(1990) The Growth of Multinationals and the Catching Up Effect, Economic Notes, Vol. 19, July, pp 1-23

Chen, E. (1983) Multinationals from Hong Kong, in S. Lall (Ed) The New Multinationals, John Wiley, Chichester, pp 88-136

Chen, T.-Y., and Y.-P. Chen (1995): Taiwanese Foreign Direct Investment: The Risks of De-Industrialization, in Journal of Industry Studies, Vol. 2, No. 1, pp. 57-68

Contractor, F. (1993) Technology Acquisition Choices for Newly Industrialising Countries: The Case of Taiwan, International Executive, Vol 35, pp 385-412

Dicken, P. (1992) Global Shift, Paul Chapman, London

Dowrick, S. (1992) Technological Catch Up and Diverging Incomes: Patterns of Economic Growth 1960-88 The Economic Journal, Vol 102,May, pp 600-610

Dunning J.H. (1981) Explaining The International Direct Investment Position of Countries : Towards a Dynamic or Developmental Approach, Weltwirtschaftliches Archiv, Vol 119, pp 30-64

Dunning J.H. (1988) Explaining International Production, London, Unwin Hyman

Dunning, J.H. and Narula, R. (1994) Transpacific Direct Investment and the Investment Development Path: The Record Assessed, Essays in International Business, March

Dunning, J.H. and Narula, R. (1996) The investment development path revisited: some emerging issues, in J. Dunning and R. Narula (eds), Foreign Direct Investment and Governments: Catalysts for Economic Restructuring. London: Routledge.

Ernst, D. and D. O'Connor (1989) Technology and Global Competition - the Challenge for Newly Industrializing Economies, Paris: OECD

ESCAP (March 1991): Industrial Restructuring in Asia and the Pacific, Bangkok: United Nations

Han, C. Min and Th. Brewer (1987): Foreign Direct Investments by Korean Firms: An Analysis with FDI Theories, Asia Pacific Journal of Management, Vol. 4, No. 2, pp. 90-102

Harrold, P. and Lall, R. (1993) China Reform and Development in 1992-93, World Bank Discussion Paper No 215

Hikino, T. and Amsden, A. (1994) Staying Behind, Stumbling back, Sneaking Up, Soaring Ahead: Late industrialization in Historical Perspective, in W. Baumol, R. Nelson and E. 
Wolff (eds), Convergence of Productivity: cross Country Studies and Historical Evidence, Oxford University Press, New York.

Hoesel, R. (1996): Taiwan: Foreign Direct Investment and the Transformation of the Economy, in J. Dunning and R. Narula (eds), Foreign Direct Investment and Governments: Catalysts for Economic Restructuring, London: Routledge,pp. 280-315

Khan, K.(1987) (ed) Multinationals of the South, London, Francis Pinter

Kojima, K. (1978) Direct Foreign Investment: A Japanese Model of Multinational Business Operations, London, Croom Helm.

Kumar, K and Mcleod, G, (eds) (1981), Multinationals from Developing Countries, Lexington Books

Lall, S. (1983) Third World Multinationals, Chichester, John Wiley

Lecraw, Donald (1977) Direct Investment by Firms from Less Developed Countries, Oxford Economic Papers, pp 442-457

Lecraw, D.(1993) Outward Direct Investment by Indonesian Firms: Motivation and Effects, Journal of International Business Studies, Vol 24, No 3, 589-600

Lee, J. (1992) Capital and labor mobility in Taiwan, in G. Ranis (ed.), Taiwan: from developing to mature economy, Boulder: Westview Press

Narula, R. (1996) Multinational Investment and Economic Structure, Routledge, London

Ozawa, T. (1979) Multinationalism, Japanese Style, Princeton, Princeton University Press

Ozawa, T. (1992) Theory of FDI as a Dynamic Paradigm of Economic Development, Transnational Corporations, Vol 1, No 1, February

Ozawa, T. (1995) Structural upgrading and concatenated integration, in D Simon (ed) Corporate Strategies in the Pacific Rim: Global versus Regional Trends, Routledge, London, pp 215-246

Perkins, D. (1994) There are at least three models of East Asian development, World Development, Vol 22, No 4, pp 655-61

San Gee (1992) Taiwanese Corporations in Globalization and Regionalization, Paris: OECD. Technical Papers No. 61

Tolentino, P.E. (1993) Technological Innovation and Third World Multinationals, London, Routledge

United Nations (1993) Transnational Corporations From Developing Countries: Impact on Home Countries, New York,United Nations

UNCTAD (1994) World Investment Report 1994, United Nationa, Geneva 
UNCTAD (1995) World Investment Report 1995, United Nations, Geneva

UNCTC (1991) World Investment Report 1991, United Nations, New York

Wade, R. (1990) Governing the Market: Economic Theory and the Role of Government in East Asian Industrialization, Princeton NJ, Princeton University Press

Weng-Jeng Kuo (1993) Internationalization of Taiwan Industry: Globalization of Taiwan's Small- and Medium-Sized Enterprises, Taipei: CIER Working Paper

Whitley, R. (1992) Business Systems in East Asia: Firms, Markets, and Societies, London, Sage

World Bank (1994) The East Asian Miracle,Oxford, Oxford University Press

World Bank (vd) The World Development Report, Oxford, Oxford University Press

Zhang, H-Y., and Van Den Bulcke, D. (1996) China: Rapid Changes in the Investment Development Path, in J. Dunning and R. Narula (eds), Foreign Direct Investment and Governments: Catalysts for Economic Restructuring, London: Routledge, pp. 380-422

\footnotetext{
${ }^{1}$ Although increasingly redundant, we use the terms 'developing countries' and 'third world' interchangeably throughout this paper. Likewise, we do the same for 'developed' and 'industrialised'. However, the use of alternative groupings such as 'OECD”' and 'non-OECD' countries are equally counter intuitive. ${ }^{2}$ See especially Wells (1983), Lall (ed) (1983), Kumar and McLeod (eds) (1981), Khan (ed) (1986)

${ }^{3}$ Similar conclusions are drawn in the work of Ozawa (1992, 1995). Although Ozawa's work utilises a different argument, the concept is essentially the same as the revised IDP.

${ }^{4}$ It is generally accepted practice that the sales of MNEs are considered as a monotonic function of its stock (see Dunning 1993 for a review of the literature)

${ }^{5}$ Data is based on UN (1995), but due to the inconsistencies in this publication, is adjusted based on earlier UN reports (see especially UN 1993).

${ }^{6}$ This is also the view propagated by Lall (1983)

7 There are nonetheless many examples of market-seeking investments. See Table 9.11 and Table 10.14 in Tolentino (1993) for a description of several such investments.

${ }^{8}$ There is nothing to suggest that this has changed, although a large share of this re-investment may now be from Taiwan. The use of overseas subsidiaries as a means to channel foreign capital is not limited to conventional MNEs. Harrold and Lall (1993) point out that up to $25 \%$ of China's inflows represent reinvestment of capital by Chinese MNEs based in Hong Kong (and are therefore recorded as outflows from Hong Kong)

${ }^{9}$ Although Mexico meets this criteria, much of the outward FDI stock represents a few large investments in a neighbouring country (USA) with which it has significant economic ties due both to its physical proximity and within the framework of NAFTA.

${ }^{10}$ See Hikino and Amsden (1994), Dowrick (1992). See also Table 2.

${ }^{11}$ It is to be noted that the second wave investors have in fact been outward-oriented, export-oriented for over three decades.

${ }^{12}$ In the early 1970 s, investments in timber projects and construction were more dominant (Han and Brewer, 1987).

13 Data on Taiwanese FDI are known to be notoriously unreliable. For a discussion on the caveats of Taiwanese data sources, see van Hoesel (1996).
} 
${ }^{14}$ Taiwanese firms were forbidden to invest in the PRC. Firms circumvented this ban by investing via shell companies registered in third countries (mainly Hong Kong).

15 FDI in banking \& insurance can be considered a response to the worldwide liberalisation of financial markets and the deregulation of financial markets in Taiwan (Lee, 1992).

16 The distinction between Heckscher-Ohlin, undifferentiated and differentiated Smithian industries respectively was made by Ozawa $(1992,1995)$.

${ }^{17}$ OEM agreements are contractual agreements by which a foreign firm orders in volume products which the OEM supplier agrees to make according to its precise specifications.

${ }^{18}$ As a result, wages in industrial sectors for the 3 years between 1990 and 1992 increased by 20.2\%, 16.9\% and $16.9 \%$ in Korea. Corresponding figures for Taiwan are $13.5 \%, 11.0 \%$ and $10.3 \%$ respectively.

${ }^{19}$ Between 1986 and 1990, for instance, the Korean Won appreciated with 16.8\% against the US Dollar. The New Taiwan Dollar went up with no less than 33.5\% against the US Dollar between 1986 and 1992.

${ }^{20}$ For an analysis of differences between Korean and Taiwanese (Chinese) family business systems, see Whitley (1992).

${ }^{21}$ The following figures clearly illustrate this point. In the beginning of the 1990s, the ten biggest companies in Korea employed 515,000 people vis-a-vis 76,000 in Taiwan. Moreover, the average sales/firm amounted to US $\$ 13,381$ million in Korea versus only US $\$ 1,997$ million in Taiwan. Furthermore, the ten leading companies in Korea realised $47.1 \%$ of GNP whereas in Taiwan they accounted for a modest $9.3 \%$. 